\title{
Prevention Of Hiv / Aids in The Behavior of Male Sex (Lsl)
}

\author{
Wiwin Mintarsih Purnamasari ${ }^{1}$, Herni Kurnia ${ }^{2}$, Anggia Puspita $^{3}$, \\ Wawan Rismawan ${ }^{*}$ \\ 1,2,3Midwifery Diploma, Poltekes Kemenkes Ri Tasikmalaya, West Java, Indonesia \\ ${ }^{4}$ Nursing Diploma, Stikes Bth, Tasikmalaya, Indonesia
}

\begin{abstract}
HIV and AIDS is a disease that continues to develop and has become a global problem that is sweeping the world. HIV is a virus that attacks the white blood cells in the body (lymphocytes) which causes a decrease in human immunity, while AIDS is a symptom of a disease that arises due to decreased immunity. In these cases, it is often found that someone who has sex with the same sex or what is commonly known as LSL / MSM (Lelaki Seks Lelaki / Male Sex With Men) is a risk group that is susceptible to HIV-AIDS. The percentage of HIV positive AIDS cases in Indonesia in 2018 in men was 63.8\%. In 2018 out of 99 cases, 55 people who tested positive for HIV / AIDS were LSL in Tasikmalaya City. This study aims to obtain information about HIV and AIDS prevention behavior in LSL related to the length of time they were LSL, perceptions of positive and negative behavior of being LSL, access to information, personal freedom, and measures to prevent HIV and AIDS transmission. This research design is descriptive with a qualitative approach. The informants were selected using the snowball sampling technique with 3 informants from the LSL Community in the city of Tasikmalaya and 1 informant from the AIDS Prevention Commission. The results showed that the informants 'attitudes and behavior control influenced the informants' intention to take HIV and AIDS prevention, such as using condoms and regularly participating in counseling and VCT tests.
\end{abstract}

Keywords: Lelaki Sex Lelaki (LSL), HIV / AIDS prevention behavior.

\section{Introduction}

HIV (Human Immunodeficiency Virus) is a virus that attacks the immune system. The infection causes sufferers to experience decreased immunity so it is very easy to become infected with various other diseases. AIDS (Acquired Immuno Deficiency Syndrome) is a group of symptoms of reduced selfdefense ability caused by the entry of the HIV virus 1 .

The increasing incidence of HIV / AIDS cases is still of concern to the world, both globally and regionally. The spread of HIV evenly in various countries starts from the African continent which is in the first rank with 25.7 million people, followed by countries in Southeast Asia with 3.5 million people. Indonesia is one of the countries in Southeast Asia and in 2017 it was ranked first which is estimated to be the largest contributor to PLWHA (People With HIV / AIDS) in Southeast Asia, amounting to 630,000 people, followed by Thailand with 440,000 people2.

The number of HIV / AIDS sufferers can be described as an iceberg phenomenon, in which the number of reported sufferers is much smaller than the actual number. This shows that the actual number of HIV / AIDS sufferers in Indonesia is not yet known with certainty. Based on the 2018 Indonesian Health Profile, the estimated number of people with HIV in
Indonesia in 2018 was 641,675 people with 46,372 new infections and 38,734 deaths 1 . The percentage of HIV positive and AIDS cases in 2018 was greater for men than for women. HIV positive patients were $63.8 \%$ in men and $36.2 \%$ in women. Meanwhile, $67.2 \%$ of AIDS sufferers in men and $32.8 \%$ in women. HIV can be transmitted through sexual contact, blood transfusions, sharing needles and transmission from mother to child (perinatal)1.

Based on data from the West Java Health Office, the estimated number of HIV / AIDS cases in 2017 was recorded at 6,990 people. The distribution of reported HIV positive cases in 1989-2017 was found mostly in Bandung City, followed by Bekasi City and Bogor City. The lowest HIV positive cases were reported from Banjar City. An increase in the number of AIDS cases in West Java occurred in 2016 and decreased again in 2017, but the incidence of AIDS cases in 2017 was higher than in previous years except in 2016. As for the incidence based on sex, many AIDS cases were reported to be sex male, namely $67.54 \%$ 3.

Based on data from the Health Office of the City of Tasikmalaya, the estimated number of HIV / AIDS cases in 2018 was 99 cases. Four sufferers have died. 


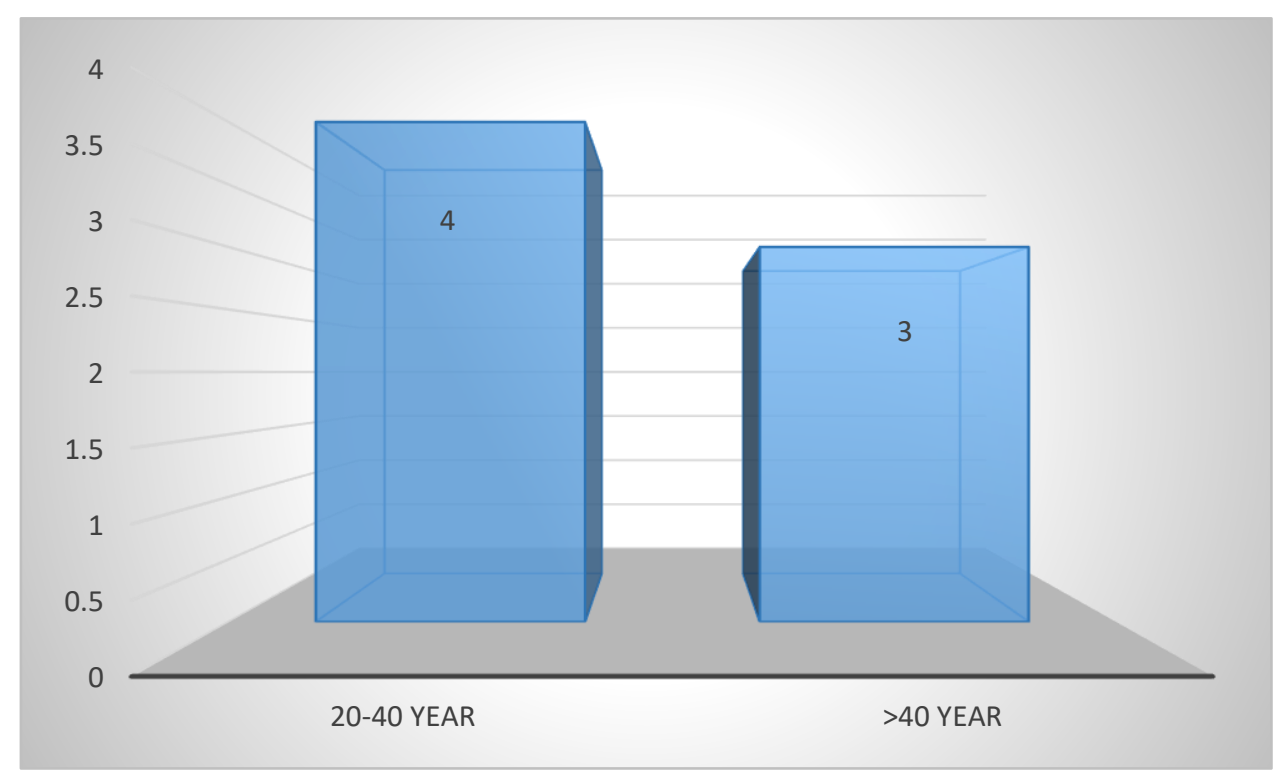

Graph 1: HIV-AIDS Cases by Age

The phenomenon of cases according to the type of work affected by HIV-AIDS was 38\% of workers, according to sex, the most infected was male, $73 \%$. And according to the route of transmission, which is $58 \%$ homosexuals, this is because the population that contributes the most to the incidence of HIV-AIDS in the City of Tasikmalaya is LSL (Men Sex with Men), out of 99 cases, 55 LSL in the city of Tasikmalaya are positive for HIV / AIDS. .4 The estimated number of LSL key population according to the 2016 Ministry of Health was 1814 people, with the results of mapping in Tasikmalaya City in 2018 as many as 401 people. And according to the case finding in health services, the most cases were found in Dr. Soekardjo Regional Hospital, namely 63 cases and in the Puskesmas Cipedes, the most were found in Puskesmas Cipedes, namely 9 cases 4 .

Male Sex with Men (LSL) is often associated with the spread of the HIV / AIDS virus because it is a form of sexual behavior disorder. LSL is an abbreviation of men who have sex with men which is taken from the word men who have sex with men (LSL). LSL is the sexual behavior of men who have sex with men, regardless of motivation to engage in sex or identification with existing or uncertain communities5.

Most HIV / AIDS infections are transmitted through sexual contact. In some countries, gay sex behavior, injecting drug use and sex work are significant risk factors6. Various efforts have been made by the Government to prevent the spread of the HIV virus among gays, through the AIDS Prevention Commission (KPA) since 2012. As an effort to prevent HIV / AIDS, a routine condom distribution program for gay groups by KPA has been running. In addition to the distribution of condoms, the use of VCT (Voluntary counseling and Testing) services by groups at risk of HIV / AIDS is an effective public health strategy for prevention as well as an entry point for case management services and care, support, and treatment for ODHA.

Researchers conducted research in the Tasikmalaya City Area on a population of LSL communities who have collaborated with each Puskesmas who routinely provide VCT / PICT services every 3 months, from the description discussed, it is important to conduct research on the description of LSL behavior in HIV / AIDS prevention to obtain direct and more in-depth information on the behavior of LSL that can cause HIV / AIDS.

\section{Method}

This type of research is qualitative research with triangulation of sources as a method for data collection which was conducted for 5 months. Informants are LSL who are determined based on the principles of suitability and adequacy to achieve data saturation. Informants were selected based on snowball sampling. In-depth interviews were conducted with 7 informants from the LSL Community and 1 informant from the AIDS Commission, and 1 informant from the family. The data analysis used the Miles and Huberman model which was carried out interactively and continued to completion, so that the data was saturated. Data collection is done through recording via cellphone devices and social media applications. During data collection, the research ethical protocols and health protocols during the Covid-19 pandemic period were consistently implemented.

\section{Result And Discussion}

The research data were obtained by interviewing the informants through triangulation of sources. In order for this research to be more objective and accurate, in addition to the data being obtained from the main 
informant, researchers are also looking for additional information by conducting in-depth interviews with supporting informants.

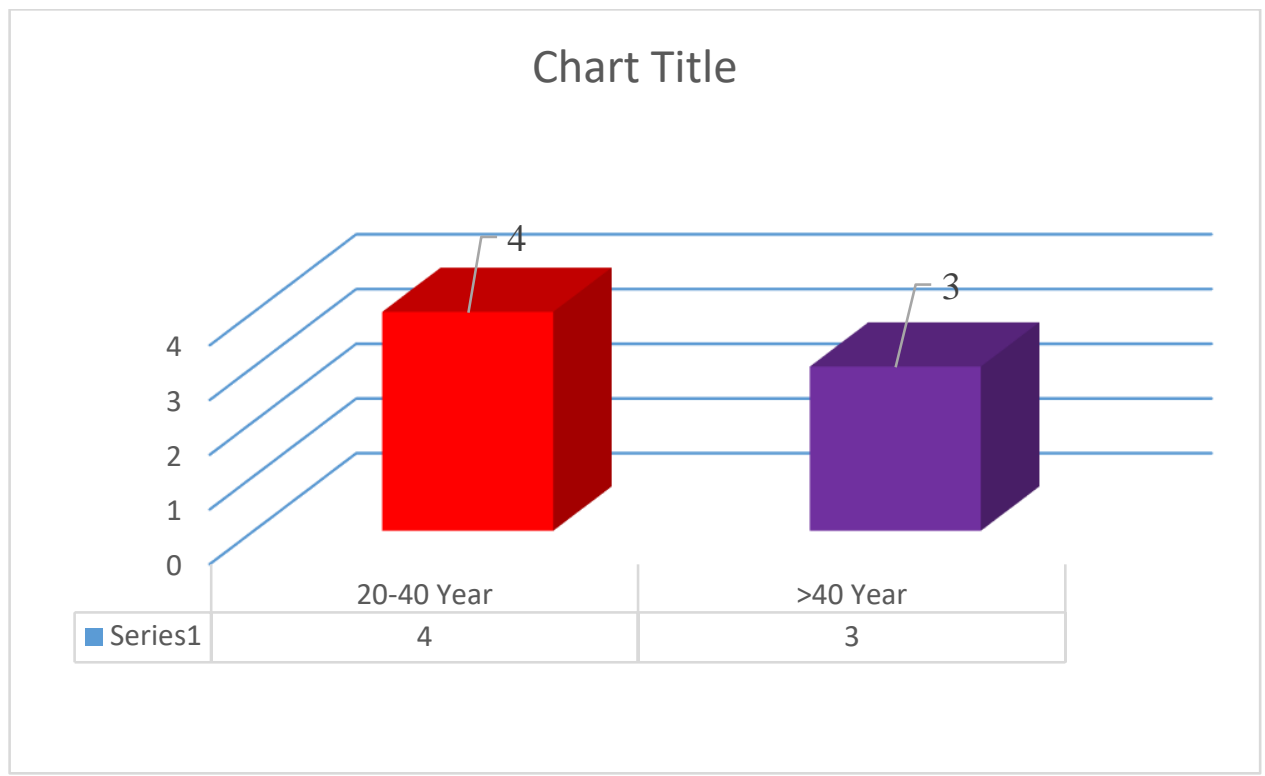

Graph 2: Age of informants

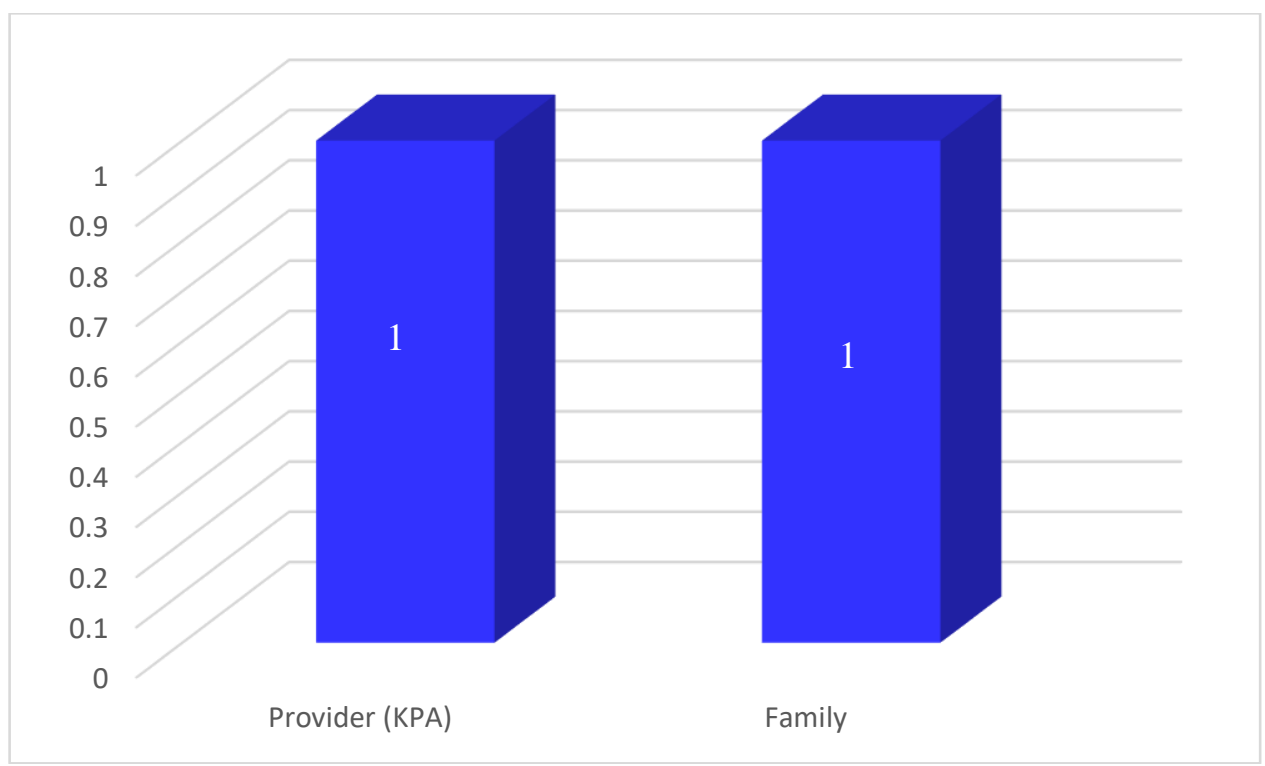

Graph 3: Criteria for Supporting Informants

The data collected from the informants on the questions the researcher asked were written as completely as possible in accordance with the results of the recordings and the results of the attached notes.

\section{Theme 1: Regarding the length of time being LSL}

The responses of the informants regarding the length of time being LSL were divided into 2 sub-themes, namely responses to their own desires and because of their influence in association. In the informant's response to his own desires, the informant felt the feeling of not being afraid, but from time to time he was uncertain about his feelings. Whereas the response due to influence in the relationship, informants feel a sense of fear of not being accepted in their interactions, but if they are part of the LSL community they are worried that they will not get satisfaction.

\section{Theme 2: interaction in the LSL community}

Intercourse in the LSL community is divided into 2 subthemes, namely association in small groups with the category of all LSL members. Meanwhile, the social category in other groups is carried out in heterogeneous interactions, in which the members mingle with normal people.

\section{Theme 3: LSL privacy with family}

The identity of an LSL is something that is kept secret from him to his family because this is a behavior deviation that can tarnish the family's good name because culture in Indonesia is closely related to customs and religion. So that from this theme, subthemes can be taken, namely unknown by the family, 
and there are 2 categories, namely suspected and not suspected.

\section{Theme 4: LSL's first meeting with their partner}

Sexual deviance in LSL is channeled by looking for same partners. The current condition is very easy to interact with someone both near and long distances. The first meeting that was held when having deviated sexual behavior with a partner who was known through social media and their social environment, data was obtained that LSL couples had sexual intercourse and did not have sexual intercourse.

\section{Theme 5: Perceptions of LSL}

Being an LSL has perceptions and points of view from various groups such as from the person of the LSL themselves and from the perspective of the community which is closely related to customs and religions.

Broadly speaking, the perception of LSL perpetrators is positive, because according to them it does not interfere with the privacy of others and is done consensually. However, there is a small proportion of LSL who have negative perceptions but because it has become a necessity, they ignore the negative perceptions that the community complains about.

\section{Theme 6: LSL knowledge about HIV / AIDS}

Most of the informants had sufficient knowledge about the dangers of HIV / AIDS infectious diseases. However, in reality, the sufficient knowledge obtained from various media is not directly proportional to health behavior in preventing the transmission of HIV AIDS.

Theme 7: LSL responses to friends or partners who are HIV / AIDS positive

For LSL circles to hear that their peers who have contracted HIV / AIDS are no longer taboo, this is the most feared impact of sexual deviance. The feelings conveyed if there is a partner who is positive for HIV / AIDS are feeling concerned and sad. The first category of LSL actors giving responses must be introspection and self-improvement. Meanwhile, in the second category, LSL will continue to live a social life in the community by taking precautions only. In the third category, the response of LSL actors would not have sexual relations with their partners and would still provide support.

\section{Theme 8: KPA Program}

The informant stated that the program from the KPA regularly runs every 6 months. The services provided are in the form of VCT tests with invitations to LSL on a regular basis and distribution of free condoms, either given by officers or LSL asking for condoms to officers.

\section{Theme 9: HIV / AIDS prevention behavior}

Because HIV / AIDS is a disease that is feared by LSL, from this theme, one sub-theme was found, namely LSL using condoms when having sex with two categories, namely the condom is safe enough to prevent HIV / AIDS and is not completely safe but rather than not using it. at all, LSL continued to use it for the sake of prevention.

As the importance of the position of the data in research, ensuring the correctness of the data is also a job that should not be ignored because good and correct data will determine the results of a study, therefore the researcher conducted an interview with the head of the KPA as a supporting informant to test the validity of the data that was done with the main informant.

\section{Theme 1: Parties involved in the P2 HIV / AIDS} Program

In carrying out the P2 HIV / AIDS program there are several related parties involved in carrying out the task, because it is very difficult to go directly to the field so that the DINKES and KPA need assistance from NGOs and PE or educated peer educators to reach LSL.

\section{Theme 2: LSL Community in Tasikmalaya City}

The estimated number of LSL key population according to the 2016 Ministry of Health was 1814 people, with the results of mapping in the City of Tasikmalaya in 2018 as many as 401 people. which makes the number of LSL in the city of Tasikmalaya many because there are many outsiders who are recorded by NGOs.

\section{Theme 3: KPA Program in Tasikmalaya City}

The main informant said that if the officers routinely participated in VCT checks carried out by officers as an effort to prevent HIV / AIDS, this was relevant to what the supporting informants said that VCT was routinely carried out every six months, but the awareness of LSL to check VCT was more who already felt symptoms. compared only for prevention.

Theme 4: KPA's hopes for LSL in HIV / AIDS prevention

After being scheduled to implement an HIV / AIDS prevention socialization program for LSL, KPA has hopes that those involved in sexual deviations can be more aware of the importance of preventing HIV / AIDS transmission, besides that there is also a longterm idealistic program that has been designed but is hampered by another reason.

Analysis of the research data aims to determine the description of LSL behavior in HIV / AIDS prevention in Tasikmalaya City in 2020 which was obtained from the results of interviews with 3 main informants and 1 supporting informant based on interview guidelines made by researchers. The results of the interview with the informant showed that the researcher got 9 themes including:

\section{Regarding the length of time as LSL in Tasikmalaya City}

In this theme, it discusses the background of the informant to become a LSL, the answers of the three informants were very diverse so that the researcher could describe them in two sub- 
themes with their respective categories.

\section{1). The sub theme of desire for own feelings}

The background of the informant having sexual deviant desires is because the feeling grows by itself, initially when the feeling comes, the informant feels strange and uncertain and feels there is an abnormality in himself so that he himself considers it a disgrace that must be endured and covered up, the informant covers it with how to find a partner of the opposite sex but this could not stem his sexual desire for the same sex so that the informant finally looked for a same-sex partner. After all this time, the feelings he felt were considered normal and did not feel afraid and uncertain, especially after knowing that it was not himself who had deviant sexual desires.

\section{2). The sub-theme is falling apart by socialization}

In addition to this feeling arises because it comes by itself, the environment has a very big influence in shaping a person's behavior, both positive and negative behavior, including that experienced by one of the informants since moving domicile for work in the Tasik city, the informant associates with someone who has deviated sexual desires so that he fell and became a LSL. Initially, the informant was afraid because of what he was doing, but on the one hand it had become a habit and a need because the informant claimed to be able to make money from this sexual deviation.

According to Notoatmodjo S (2010), behavior is the result of all kinds of experiences and human interactions with the environment which are manifested in the form of knowledge, attitudes and actions. Behavior is an individual's response / reaction to stimuli that come from outside or from within him.

And according to A. Wawan \& Dewi M (2011), behavior is an action that can be observed and has a specific frequency, duration and purpose, whether consciously or not. Behavior is a collection of various interacting factors.

\section{Tasikmalaya City LSL Community}

The LSL community in Tasikmalaya was not formally formed as the city of Tasikmalaya with a routine schedule held for the association. This theme is outlined in Figure 4.2.1.2. in the chart there is one sub-theme with its category.

\section{1). Small Group Sub theme}

Informants said that they only had a small group and gathered and mingled with others. This was confirmed by the head of the KPA as a supporting informant that the LSL community only exists on social media such as Facebook and others, and even then only social media groups can be accessed by everyone and not only official gathering schedules. Because the community is only a small group. however, there are many small groups so that the
DINKES and KPA collaborate with NGOs to reach out to LSL groups in order to carry out extension activities and VCT examination programs. The number of LSL in the city of Tasikmalaya also looks very large, but this is because many migrants from outside the city are recorded by NGOs, because NGOs record the number of LSL present at that time also in the swiping area.

\section{LSL privacy with family}

LSL forget about one of the sexual deviations, so someone who has this sexual desire even though they already feel comfortable and are not afraid of their feelings, they still keep their identity secret in the public, especially their family.

\section{1) Sub-theme Not known by his family}

All informants interviewed said that they very much guarded their privacy in front of their families and behaved like normal people, this was done to maintain the good name of the family, especially their parents because the function of the family is to develop offspring morally and socially. Moreover, culture in Indonesia is closely related to customs and religious norms. However, there was also an informant who said that his family's privacy was not known, but he felt that one of his family was suspicious of him because he did look graceful and his parents had asked when he was going to get married, this made the informant feel that His parents began to suspect him, but this was not conveyed to the informants because the parents wanted to protect their child's good name. Even though suspicions had arisen, the informant still did not feel guilty and remained calm about his days as an LSL.

Sexual deviations that occur in society have a disharmonious impact on the survival of socializing, not only that, the most dangerous impact is that perpetrators of sexual deviants are susceptible to infection with diseases. If the impact of these deviations does not immediately get the attention of the authorities, there will be a breakdown in the social order built on the prevailing values and norms.

According to Paul B. Horton (1996), deviant behavior is any behavior that is stated as a violation of the norms of a group or society, while according to Robert MZ Lawang (1985), deviant behavior is an act that deviates from the prevailing norms in the social system and causes the efforts of those who are authorized in the system, to correct this deviant behavior. Thus, this deviation is behavior that violates the norms in a group or society. When community groups see a form of deviation, they will unilaterally reject it, because it is not in accordance with behavior, norms or rules that violate normal habits.

\section{LSL meeting with their partners}

In channeling their sexual desires, LSL will look for dating partners either in their neighborhood or on social media. 


\section{1) Social Media Sub Themes}

Social media has become a necessity today, because it contains various information and one of them can be used as an intermediary in making friends. LSL take advantage of this to find their date easily, because currently there is a special dating application for homosexuals and to get it is very easy because it is available in the play store or app store. The informant admitted that he could change partners easily, but the informant said that in order to have sex, the informant had to know the history of his partner because he was afraid to have symptoms of STI or HIV disease, but there are still many LSL who do not pay attention to this and that is what causes the rate of sexual deviance. and HIV / AIDS positive cases in Indonesia and even in the world are increasing.

\section{2) Sub-theme environment}

Apart from social media, the environment also has a very big influence and the opportunity to get a partner, but it will be a little difficult compared to finding a partner on social media because an LSL will not show his identity in the community, this is what will have an effect in subjecting someone to sexual deviance The informant said that he could become LSL because of the association in his environment, it happened initially just as just a friend, but the longer his friend paid more attention like paying attention to a partner and that was what made the informant comfortable so that he changed his sexual orientation.

According to Sarwono (2011), there are several factors that influence sexual behavior, namely:

(1). The dissemination of information and stimulation of sexuality through the mass media and the presence of sophisticated technology has become unstoppable.

(2). The family socialization process in the main environment, namely the family environment, campus environment and community environment. Where peer groups play an important role in the lives of adolescents. Youth want to be accepted and viewed as members of peer groups, both at school and in society. So the social environment that adolescents enter can have an effect on pressuring adolescents to have sex, because of the desire to be accepted by the social environment.

\section{Perceptions About LSL}

Being a LSL will certainly get a view with positive and negative perceptions, both from himself or others.

\section{1) Sub-chapter positive perceptions}

Positive perceptions of being a LSL are the perceptions of the informants themselves because only herself and her community feel the positive side of being a LSL is not from the views of others, informants said they get inner satisfaction and can express their desires with their partners, besides that they can also have many friends. both from the region as well as from other regions.

\section{2) Sub-chapter negative perceptions}

Meanwhile, the negative perception of being a LSL is another person's judgment in the community. Because the Indonesian people consider LSL as a sexual deviation that has violated the norms of customs and religion, therefore there will be socalled social conflicts, including social restrictions and the worst will be discrimination and criminalization. Therefore, an LSL will cover up their identity in social life.

\section{LSL Knowledge About HIV / AIDS}

Based on data from the Health Office of the City of Tasikmalaya, the estimated number of HIV / AIDS cases in 2018 was recorded that 99 cases of the population that contributed the most to the incidence of HIV-AIDS in the City of Tasikmalaya were LSL (men sex with men), of the 99 cases, 55 were LSL in the city of Tasikmalaya. positive for HIV / AIDS, from the data above, it is very questionable how the knowledge of LSL about HIV / AIDS.

\section{1). Sub chapters know about the dangers of HIV / AIDS}

After conducting interviews with informants, they learned about HIV / AIDS, starting from the understanding, transmission to the signs that someone has HIV / AIDS. They get this knowledge from counseling and this extension is one of the KPA programs, the extension is carried out during VCT examinations held at puskesmas or restaurants, besides PKBI NGOs also train someone in the community to become PE (educated peer educators) so that Extension materials can be conveyed and the target of socialization will not be awkward to hold discussions. In addition, informants also get knowledge from social media, because in social media there are search engine tools that contain a lot of information including information about HIV / AIDS. If LSL already know about the dangers of HIV / AIDS, the problem with the high rate of HIV / AIDS for LSL is that their level of awareness of their behavior is still too low.

According to Kholid and Notoadmodjo (2012) there are 6 levels of knowledge, namely: 1) Know (Know) A sense of understanding seeing or observing something 2) Understanding (Comprehension) an ability to explain about an object that is known and interpreted correctly according to facts 3) Application (Application) An ability to practice the material that has been studied in real or actual conditions 4) Analysis the ability to describe or explain an object or material but it is still related to one another 5) Synthesis An ability to connect parts in a new whole form 6) Evaluation (Evaluation) Knowledge to make an assessment of a material or object.

7. LSL Responses To Friends Or Partners Who Are HIV / AIDS Positive 
IMS (sexually transmitted infections) and HIV / AIDS are the diseases most feared by LSL, so that this will never be separated from the consequences of sexual deviance committed by LSL. Although they are very feared, LSL are not yet able to control their behavior. This theme is described in Figure 4.2.1.7 with one sub-theme and its category.

\section{1). Sub-theme if friends / partners affected by HIV / AIDS are concerned and sad}

LSL are no stranger to hearing that their friends or partners are HIV / AIDS positive, this is a reflection for them to be more careful, the informants said they were very sad and were concerned if a friend or partner had HIV / AIDS, PLWHA really needs support from their friends in order to stay calm in their life and not to be stressed because they have to take medication for the rest of their life, get social sanctions and their health will continue to decline. From this incident, one informant out of three conducted self-reflection and improved because of her advanced age, while another informant said that she would stop sexual activity with her partner if she was positive for HIV / AIDS, and would continue sexual activity if only her friend was affected, but the informant will take precautions so as not to become infected by wearing protective equipment such as condoms, this was said by an informant who was still young and thought that his standard of living was still long.

\section{The KPA Program}

The Tasikmalaya City Health Office and the AIDS Prevention Commission have a program called the HIV / AIDS Control Program or P2, which this program has been running regularly. This theme is described in Figure 4.2.1.8 with 2 sub-themes and their categories

\section{1). VCT Test Sub-Theme By Invitation}

VCT examination is a compulsory examination as a prevention and detection of whether a person has HIV / AIDS or not, therefore all informants said that they always routinely participate in VCT examinations if there is an invitation from the officer as an action to prevent HIV / AIDS transmission. However, supporting informants said that the VCT examination was not based on the awareness and desire of LSL, so KPA made a routine schedule every 6 months by giving invitations to LSL for VCT examinations and also socialization. DINKES and KPA are also partnering with PKBI NGOs to be able to reach places where LSL are gathered because NGOs are reachers who can mingle with risky groups to persuade them to want to get checked out. DINKES, KPA, Puskesmas and NGOs are important components in carrying out HIV / AIDS control programs, but KPA hopes that community components, especially education parties, can participate in programs such as providing student socialization related to KESPRO, IMS and HIV / AIDS.

\section{2). Distribution Of Protective Equipment In The Form Of Free Condoms}

VCT examinations are carried out by the puskesmas and their laboratories so that the distribution of free condoms is arranged by the puskesmas so that they can be given to the right people as a means of preventing HIV / AIDS transmission. The informant said that he always got free condoms from the officer after carrying out a VCT examination and when the condom ran out, the informant always asked the officer directly. KPA hopes that all groups at risk will realize the importance of using condoms to break the chain of HIV / AIDS spread.

According to the Ministry of Health (2008) Counseling in VCT is a counseling activity that provides psychological support, information and knowledge on HIV / AIDS, prevents HIV / AIDS transmission, promotes responsible behavior change, ARV treatment and ensures solutions to various problems related to HIV / AIDS.

VCT is important because it is an entry point to all HIV services, Offers benefits, for both positive and negative test results, with a focus on providing support for client needs such as behavior change, mental support, support for ARV therapy, factual and up-to-date understanding of HIV , Reducing the stigma of society, Is a comprehensive approach: physical and mental health, Facilitating access to various services needed by clients both health and psychosocial.

\section{HIV / AIDS Prevention Behavior.}

To minimize the transmission of HIV / AIDS, it is important for groups at risk to take precautions so that they do not get HIV AIDS from their partners. This theme is described in Figure 4.2.1.9 with one subtheme and its categories

\section{1). Sub-theme Using a condom during sexual intercourse}

All informants said that the way to behave to prevent HIV / AIDS transmission is by wearing protective equipment such as condoms when having sexual intercourse, although condoms do not fully protect against the dangers of transmission, they said it is better to keep using than at all. The informant said that in addition to prevention, the use of condoms is also a tool for lubrication to make it slippery during sex. In addition, they are also aware of their partners by recognizing the signs that someone has HIV AIDS. However, the relationship between knowledge and attitudes is still very low, so there are still many LSL who are not deterred from engaging in sexual deviant activities even though their friends or partners have HIV / AIDS. KPA as the supporting informant also hopes that all LSL are consistent in taking precautions so that the HIV / AIDS transmission rate can be controlled. In addition, KPA also hopes that the longterm idealism in the form of a rehabilitation boarding school can be realized in order to attract risk groups back into normal sexual activity.

According to Purwoastuti 2015, behavior is an action 
or human activity itself which has a very wide expanse such as walking, talking, crying, laughing, working and others, both directly and indirectly observed. Skinner (1938) a psychologist stated that behavior is a person's response or reaction to a stimulus (external stimuli), therefore this behavior occurs through the process of a stimulus to the organism and then the organism responds.

\section{Conclusion And Recommendations}

Based on the results of qualitative research using interview techniques conducted in the City of Tasikmalaya, Regarding the description of LSL behavior in HIV / AIDS prevention in Tasikmalaya City in 2020, the following conclusions can be drawn:

A person's background as LSL is influenced by internal and external factors, namely feelings that arise in himself and the influence of the environment. And for a long time being a LSL, there are those who have felt it since they were young and since they have been influenced by their social environment.

In their association, LSL in the city of Tasikmalaya do not have an official community so that only a small group or can be called a group or gang, even some groups have members mingle with normal people on the basis of common hobbies. The identity of an LSL is very much guarded by himself because it is to protect the good name of himself and his family.

There are also various places for LSL to find their partners, some get it from social media via a dating application specifically for homosexuals and some also get partners from their social environment.

Informants' knowledge about HIV / AIDS was quite good, most informants were able to answer and explain the meaning, symptoms felt after the introduction of HIV, transmission, prevention and treatment of HIV / AIDS. These factors, namely, the existence of trainings held by parties related to the HIV / AIDS program, and the provision of knowledge during the VCT process as well as knowledge from peers.

Positive perceptions of being a LSL are only felt by the perpetrators themselves because they can channel their sexual desires and can make friends, while negative perceptions are obtained from the community because Indonesia is a country that obeys religious customs and norms so that if they do so, that person will get social sanctions .

HIV / AIDS prevention behavior is carried out by wearing protective equipment such as condoms, participating in counseling activities and will routinely follow VCT examinations held by the Health Office and KPA.

\section{References}

1. Kementrian Kesehatan RI. Profil Kesehatan Indonesia. Jakarta; 2018

2. World Health Organisation. HIV/AIDS [document on the Internet]; 2018. Available from: https: / /www.who.int/

3. Dinas Kesehatan Provinsi Jawa Barat. Profil kesehatan Jawa Barat. Bandung; 2017.

4. Dinas Kesehatan Kota Tasikmalaya. Profil Kesehatan Kota Tasikmalaya. Tasikmalaya; 2018.

5. World Health Organization. Guidelines for intensified tuberculosis case-finding and isoniazid preventive therapy for people living with HIV in resourcesconstrained settings [document on the Internet]; 2011 [diakses maret 2016]. Available from: http://apps. who.int/

6. UNAIDS. Global AIDS Update 2016. Geneva : Joint United Nations Progamme on HIV/AIDS; 2016.

7. A.Wawan, Dewi M. Teori dan Pengukuran Pengetahuan, Sikap, dan Perilaku Manusia. Cetakan II. Yogyakarta: Nuha Medika;2011.

8. Ratnawati, M. (2014). Hubungan Kebiasaan Menonton Film Porno dengan Perilaku Seksual Remaja di SMK Sasrawati Salatiga Kelas X Otomotif. Universitas Kristen Satya Wacana. Retrieved from http: / / repository.uksw.edu/bitstream/123456789/4 867/1/T1_132010066_Judul.pdf

9. Khairunnisa, A. (2013). Ejournal psikologi, 1 (2) hal 220-229, 2013: 220-229 diunduhpada tanggal 22 Oktober 2013 dari http://ejournal.psikologi.fisipunmul.ac.id/

10. Widoyono, Penyakit Tropis Epidemiologi, Penularan, Pencegahan \& Pemberantasannya. Jakarta: Erlangga; 2011.

11. Kummar, V., Abbas, AK., Aster JC Robbins and Cotran; Pathologic Basic of Disease Ninth edition; 2015. Philadelphia :Saunders Elsevier.

12. Ditjen PPM \& PL; 2015. Laporan Perkembangan HIV/AIDS Triwulan I Tahun 2015. Jakarta: Depkes RI.

13. Grouzard, Veronique; Rigal, Jean, Sutton,Marianne. (Ed); 2016. Clinical Guildlines : Diagnosis and treatment manual. 2016 Editions. Paris : Frontieres Medecins Sans. ISBN 978-2-37585-001-5.

14. Edward C. MD, Klatt. (2016). Pathology of HIV/AIDS 27th Version. Savannah : Mercer University School of Medicine.

15. Ditjen PPM \& PL. 2012. Petunjuk klinis tatalaksana klinis ko-infeksi TB-HIV. Jakarta: Kementrian Kesehatan RI. ISBN 978-602-235-1

16. Ditjen PPM \& PL. 2011. Pedoman nasional tatalaksana klinis infeksi HIV dan terapi Antiretroviral pada orang dewasa. Jakarta : Kementrian Kesehatan RI.

17. Centers for Disease Control and Prevention (2009). CDC to distribute $\$ 40$ million in recovery act funding to help states fight healthcare-associated infections. http://www.cdc.gov diakses 15 Februari 2016.

18. Kemenkes RI (2017)‘Laporan Perkembangan HIV-AIDS \& infeksi Penyakit Menular Seksual (IMS) Triwulan I’.

19. UNAIDS. 2017. UNAIDS Data 2017.Ganeva: UNAIDS.

20. Soetjiningsih, Pemahaman Seksualitas pada Remaja. Jakarta: Sagung Seto; 2010.

21. Afiyanti, Yati, Rachmawati, Imami Nur. Metodologi 
Penelitian Kualitatif Dalam Riset Keperawatan. Jakarta: Rajawali Press; 2014

22. Lapau, Prof.Dr.Buchari,dr.MPH. Metode Penelitian KesehatanMetode IImiah Penulisan Skripsi, Tesis, dan disertai Pedoman bagi Mahasiswa S-1, S-2 dan S-3. Jakarta: Yayasan Pustaka Obor Indonesia; 2012.

23. Djiwandono P. I. Meneliti Itu Tidak Sulit: Metedologi Penelitian Sosial dan Pendidikan Bahasa. Edisi pertama. Cetakan pertama. Yogyakarta: Deepublish; 2015.

24. Fitrah, M. dan Luthfiyah. Metode Penelitian: Penelitian Kualitatif, Tindakan Kelas \& Studi Kasus. CV Jejak: Sukabumi;2017.

25. Emzir. Metodologi Penelitian Pendidikan:Kuantitatif dan Kualitatif. Jakarta: Rajawali Pers; 2010.

26. Creswell, J.W. Research design: pendekatan kualitatif, kuantitatif, dan mixed. Yogjakarta: PT Pustaka Pelajar; 2010.

27. Creswell, J.W. Research Design: Pendekatan Kualitatif, Kuantitatif, dan Mixed, ed 3. Yogyakarta: Penerbit Pustaka Pelajar;2013.

Correspondence: Wawan Rismawan, wawan_rismawan@stikes-bth.ac.id 